\title{
Using Movie to Improve Students' Narrative Writing Skill
}

\author{
Firman Aziz and Fithry Fathiyyaturrizqi \\ Universitas Pendidikan Indonesia, Bandung, Indonesia \\ Firman.aziz@upi.edu
}

\begin{abstract}
Since KTSP to 2013 Curriculum, students are expected to be able to write in many genres of writing text, including narrative text. In fact, most of EFL students often faced some difficulties in writing English text because they think that they were not be able to select proper words, use correct grammars, generate ideas, and composing their thoughts and ideas in their writing. Therefore, this Classroom Action Research (CAR) aimed to investigate how using movie could improve English narrative writing. The subjects were 44 of IX grade students at one of the Junior High School in Bandung. The data were collected through observation sheets, students' worksheet and student' journal sheets. The result of the research shows that using movie could improve students' narrative writing skill. The mean for the first cycle is $\mathbf{6 6 . 7 0}$, while the last cycle is 81.30. In addition, based on students' journal, most of students $(90 \%)$ were more motivated and confident in learning writing through movie because it was more enjoyable than conventional writing instruction. From the finding' analysis, it can be concluded that the use of movie in teaching writing could improve student' narrative writing performance.
\end{abstract}

Keywords: Movie, Narrative Writing Skill, CAR

\section{INTRODUCTION}

Writing is one of the basic communication skills in teaching learning language. The government put high emphasis on writing skill for Junior High School (SMP) and Senior High School (SMA) curriculum. Since KTSP to 2013 Curriculum, students are expected to be able to write in many genres of writing text (Educational Ministry Regulation, 2013). In fact, based on my experience in teaching English, most of EFL students often faced some difficulties in writing English text. Students were not be able to select proper words, use correct grammars, generate ideas, and composing their thoughts and ideas in their writing (Harmer, 2007; Alwasilah, 2001). In line with that, the students may also have some difficulties in pre-writing process, which is related to generating ideas and writing planning (Kim, 2007).

One of the ways to improve student's writing skill is by using narrative text. According to Kay and Humpreys (1993) in their journal "Narrative, Self-Assessment, and the Reflective Learner" said that narrative requires simply the recounting of an event or sequence of event and it deals with an experience. Moreover, narrative text is the most commonly used text in the early ages of learning (Cortazzi, 1991). Based on the Educational Ministry Regulation (Permendikbud) no 68 in 2013 curriculum about Junior High School Curriculum of English subject, narrative is chosen as one of the genre that should be learned by student. It is stated in basic competence:

\begin{abstract}
"Understanding the social function, the structure of the text, and linguistic elements of narrative text folklore, in accordance with the context of its use." (English Syllabus for IX Grade Junior High School)
\end{abstract}

Therefore, the teacher may need to adjust the methods to student' needs and create a particular strategy to improve student' writing skill ability. One of the probable strategies in teaching writing is audio visual aid particularly, movie. The use of movie is expected to develop students' narrative writing skill. Using movie as teaching media can build student' prior knowledge, support students to understand the material, help teacher to teach material effectively and interest student' motivation (Heinich et al,1982; Raiser and Dick, 1996). In line with that, Cubillos (2000) presents some evidences that movie can 1) facilitate vocabulary learning; 2) increase students awareness of language structure through more sophisticated error-feedback programs; 3) support reading and writing development; 4) help teachers keep track of student's processing of language; 5) enhance motivation and 6) enhance teaching resources through such tools are grading programs and presentation software. In addition, Nurmaliah (2010) applied the fairy-tale movie for her study to find its effectiveness in teaching writing. This technique succeeded to attract student's attention. They enthused to write down their narrative based on the movie shown.

Referring to the problems, the theories, and the related study discussed above, this study used Classroom Action Research (CAR) and proposed to investigate the improvement of students narrative writing process and to find out the students' responses toward the implementation of using movie in teaching narrative writing skill.

\section{LITERATURE REVIEW}

In the process of developing writing material, media have an important role. The material can be delivered effectively to the students if the teacher used suitable media. Movie is one of media to develop writing material. Based on oxford dictionary (2003), movie is a series of moving pictures recorded with sound that tells a story. Movie can be optional tool to foster students' critical thinking (Geddes \& Sturtridge, 1984). It help students integrate the audio and motion video then write them into a story movie. In line with that, Sand (1956) states that movie brightens up classroom and brings more variety, enjoyment and interest in language learning. It can be conclude that movie is an alternative media in teaching narrative writing.

Writing do not only writes down the ideas and thoughts into the written language, but also composes the ideas into well-organized form of writing. There are several aspects that learners should master in order to make a well- 
organized text. Brown (2001) classified the five aspects of writing: (1) Content-consist of thesis statement, related ideas, development of ideas through personal experience, illustration, facts, and opinion; (2) Organization-covers effectiveness of introduction, logical sequence of ideas, conclusion, and appropriate length; (3) Discourse-contains topic sentences, paragraph unity transitions and cohesion; (4) Vocabulary; and (5) Mechanics-consist of spelling, punctuation, neatness and appearance.

In addition, the generic structure of narrative text usually begins with orientation stages (can be paragraph), where the writers introduce the characters of the story, the time and the place where the story happened. The second stage is complication, where the conflicts arise and the main character attempts to solve the problem. The next stage is resolution, where the complication of the story is sorted out or problem is solved. The last stage is Coda, where the writers found a moral or message to be learned from the story (Anderson, 2007).

Some of studies have conducted with teaching writing through movie. Lusiana (2008) investigated the implementation of using animated movie in teaching writing. The result shows that using movie in writing classroom is very important to increase students' retention of learning and students' thinking ability in order to develop their creativity. In addition, Nurmaliah (2010) investigated the use of a fairy tale movie in teaching writing. The result shows that movie does not only helping teacher to create a meaningful instruction but also motivating students to improve their writing skill.

\section{METHODOLOGY}

This study used Classroom Action Research (CAR). Kemmis and McTaggart (1988) cited in Hopkins (1992) state that action research is an action which is conducted to inquire self-reflective and improve his/her instruction by evaluating his/her own practices. A research conducted to overcome any problem concerns teaching and learning process in a classroom called Classroom Action Research (Arung, 2014). CAR aims to improve both of students' learning and teaching method in the classroom. CAR consists of cycles and have four basic steps which are planning, acting, observing and reflecting (Nunan, 1992; Mills, 2003; Kunandar, 2008). This research used two cycles. Each cycle is conducted in two meetings. The subjects were 44 of $9^{\text {th }}$ grade students at one of the Junior High School in Bandung. The data were collected through classroom observation, interview, document analysis, students' journal and documentation of students' narrative writing.

\section{FINDINGS AND DISCUSSION}

Before starting the cycles, preliminary study was carried on to get the students' progress in writting narrative text before and after using movie. It included classroom observation, interview, and document analysis. Classroom observation and interview are used to get deep information about students' writing difficulties. Document analysis is the document that records the students' writing before using movie.

The minimum completion scores (Kriteria Ketuntasan Minimal) of the $9^{\text {th }}$ grade was 70 . Based on document analysis of students' narrative writing shows that the highest score is 80 and the lowest score is 55 . The mean was 66.70 . In addition, there were 20 students (45\%) who got the scores above KKM. Therefore, movie is introduced as an alternative media in teaching writing to improve students' narrative wriitng skill.

\subsection{The progress of students narrative writing process in every cycles \\ a. Cycle 1}

The first cycle, the teacher provide a movie entitled "Akeelah and the bee". The movie was suitable for young learners and has a good story. The teacher had designed students' worksheet that consists of three parts: (1) Mind mapping sheet-students asked to watch the movie and made outline of the story about with used mind mapping method; (2) students' writing sheet—-students asked to write down the story with their own word; (3) students' journal sheetstudents asked to draw conclusion, give suggestions, and put forward their impressions on the journal.

The result of cycle 1 shows that there was improvement in students' mean score of narrative writing after using movie. The highest score of student' writing is 90 and the lowest is 65 . The mean of cycle 1 was 72.90 . In addition, there were 34 students $(78 \%)$ who got score above KKM. The improvement of students' mean score was not satisfied because there was several weaknesses that found in cycle 1. Based on classroom observation and students' journal, the material was too difficult because the dialog in the movie was too fast and not clear enough but students seemed very enthusiastic to understand the story of the movie and they watched it carefully. The teacher had to change the material for the next cycles that most suitable for students. Therefore, the teacher decided to do cycle 2.

\section{b. Cycle 2}

In the second cycle, the teacher was designed better lesson than cycle 1 . The teacher used comedy movie which is entitled "Alvin and the chipmunks" that was interested and motivated students in writing narrative. The next step, students asked to did the student' worksheet as in the cycle 1 . The teacher tried to improve students' motivation and facilitated them to build their knowledge. The result of cycle 2 shows that the highest score of student' writing is 95 and the lowest is 77. The mean of cycle 1 was impoved on 81.30. In addition, all students (100\%) had reached the Minimum Completion Scores (KKM). Thus, the cycle was ended and considered to be successful.

Referring to the result students' narrative writing in preliminary study, cycle 1 and 2, the improvement students' mean score 66.70 to 81.30 is high enough. It can be concluded that teaching writing through movie can improve students' writing narrative skill and help teacher in 
supporting the successful teaching writing. Using movie as teaching media can build student' prior knowledge, support students to understand the material, help teacher to teach material effectively and interest student' motivation (Heinich et al,1985; Raiser \& Dick, 1996). The figure 4.1 shows the progress of students' mean score of narrative writing process and figure 4.2 shows the progress of students' score above the Minimum Completion Scores (KKM).

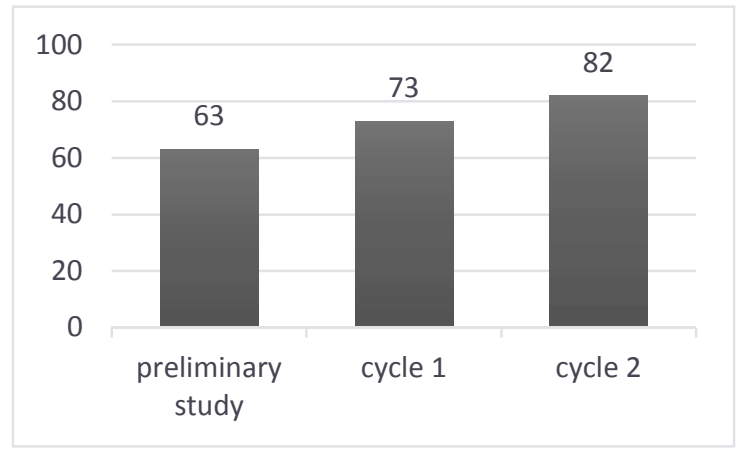

Figure 4.1 The progress of students' mean score of narrative writing process

\subsection{Students' responses toward the implementation of using movie in teaching narrative writing skill}

Based on findings from the students' journal and students' interview, twenty six students (57\%) said that they enjoy study writing through movie. This is in line with Raiser and Dick (1996) that movie helped students to understand the context of the message by watching or paying attention to the visualization, although students didn't fully understand the dialogues, they could guess the message through the movement or visualization. Therefore, movie can encourage students' motivation.

Around twelve students (26\%) said that they got new vocabulary by watching movie. Rich vocabulary can enhance students' knowledge in writing (Cubillos,2000). In addition, three students (17\%) said that movie help them in building idea in writing narrative. Students felt easier to memorize the story, then they could transform their ideas into paragraphs. This is in line with Lusiana (2008) that using movie in writing classroom is very important to increase students' memorize of learning and students' thinking ability in order to develop their creativity. Figure

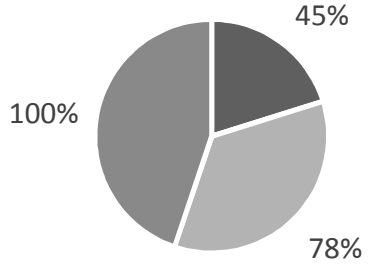

- preliminary study - cycle 1 - cycle 2

Figure 4.2 The progress of students' above Scores (KKM)

\section{3 below shows students' response of using movie in the narrative writing process}

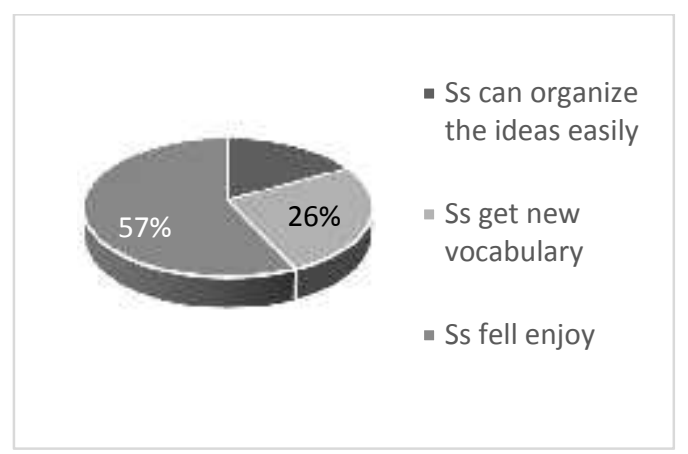

Figure 4.3 Students' response of using movie in the narrative writing process

Based on the data above, it can be concluded that students' responses toward the implementation of using movie in teaching narrative writing skill were positive. Students believed that the use of movie in teaching narrative writing can improve their narrative writing skill.

\section{CONCLUSION}

From the finding' analysis, the theories and the related literature of the study, it can be drawn some conclusions. First, movie as an alternative media can improve students' narrative writing skill. Based on students' writing product in each cycles, it discovers the improvement of students' score. A good time management and wellpreparation are required to achieve an effective teaching and learning process in using movie as teaching media.

Second, using movie enhance students' motivation in narrative writing. Students felt enjoy to understand the story of movie although they did not fully understand the dialogues, they could guess the message through the movement or visualization. Thus, students were able to undertstand the material easily. 


\section{REFERENCES}

Alwasilah, A. C. (2001). Language culture and education: a portrait of contemporary Indonesia. Bandung: Andira

Anderson, Mark \& Kathy Anderson. (2007). Text Types in English 2. Australia: Macmillan Education.

Arung, F. (2014). The conceptual framework of classroom action research. Online available at https://usnpendbing.wordpress.com/2015/03/24/theconceptual-framework-of-classroom-action-research/

Brown, H. D. (2001). Teaching by Principles: An Interactive Approach to Language Pedagogy.(2nd ed). New York: Longman.

Cortazzi, M. (1991). Primary teaching: How it is, a narrative account. London: David Fulton.

Cubillos, J. (2000). "Integrating technology into the foreign language curriculum." In J. Bragger \& D. Rice Branches. Boston: Heinle \& Heinle Publishers.

Geddes, M \& Sturtridge, G. (1982). Video in Language Classroom. London: Heinemann Educational Books.

Harmer, J. (2007). How to teach writing. Edinburg: Pearson Education Limited.

Heinich, Mollenda, Russel. (1982). Instructional Media and The New Technologies of Instruction. $2^{\text {nd }}$ Ed. Canada: John Wiley \& Sons, Inc.

Hopkins, D. (2008). A teacher's guide to classroom reseach. (4th ed). Philadelpia: Open University Press

Kim, M. (2007). Genre-Based Approach to Teaching Writing (online). Available http://web1.hpu.edu/images/GraduateStudies/TESL_ WPS/07Kim_Genre_a17238.pdf.

Kunandar. (2008). Langkah Mudah Penelitian Tindakan Kelas: Sebagai pengembangan Profesi Guru. Jakarta: RajaGrafindo Persada.

Lusiana, L. (2008). The effectiveness of using cartoon movie in teaching writing narrative text. FPBS UPI Sarjana Degree: Unpublished Paper.

Mills, G. E. (2003). Action research: A guide for the teacher researcher (2nd edition). Upper Saddle River, NJ: Pearson.

Nunan, D. (1992). Research Methods in Language Learning. New York: Cambridge University Press.

Nurmaliah, N. (2010). The use of fairy-tale movie in teaching narrative text writing. FPBS UPI Sarjana Degree: Unpublished Paper.

Raiser and Dick. (1996). What is writing? [Online]. Available at http//www.ccsf.edu/services/LAC/lem10/writing.htm

Sand, Lester. B. (1956). Audio Visual Teaching Procedure. New York: The Ronald Press

Tim Permendikbud. (2013). Permendikbud Tahun 2013 tentang Standar Nasional Pendidikan. Jakarta: Kemdikbud. 